\title{
António Apolinário Lourenço, Portugal y su literatura, del Siglo de Oro a la Edad de Plata, Madrid/Cáceres, La Umbría y la Solana/Universidad de Extrema- dura, 2021, 220 pp. ISBN: 978-84-9127-088-1
}

\section{Ignacio Arellano}

http://orcid.org/0000-0002-3386-3668

Universidad de Navarra, GRISO

ESPAÑA

iarellano@unav.es

[Hipogrifo, (issn: 2328-1308), 9.2, 2021, pp. 1109-1111]

Recibido: 22-07-2021 / Aceptado: 11-08-2021

DOI: http://dx.doi.org/10.13035/H.2021.09.02.72

De las dos secciones de este volumen, pulcramente editado por la Universidad de Extremadura (colección La Umbría y la Solana) interesa para el Siglo de Oro la primera, sin que ello merme el interés de los trabajos dedicados a la Edad de Plata (sobre Eça de Quirós, las relaciones hispanolusas en el XIX, Los pazos de Ulloa, Menéndez Pelayo y la literatura portuguesa, Espronceda y Pessoa, y Mário de SáCarneiro, pp. 93-210).

La mentada primera sección, que es ahora la que me ocupa, se compone de cuatro estudios, pero las primeras páginas introductorias merecen alguna reflexión previa. Señala Apolinário Lourenço, con muy certera perspectiva, un hecho crucial a la hora de abordar la presencia de Portugal en las letras españolas del Siglo de Oro, y es la conciencia de la época de «un espacio cultural ibérico compartido por todos los habitantes de esa misma Península, forjado en una convivencia milenaria íntima» (p. 9), unidad que las circunstancias históricas y los desencuentros sucesivos no borraron nunca. Los aludidos estudios, que examinan el teatro de Lope, Tirso y Calderón, y la obra del hidalgo portugués Francisco Manuel de Melo, evidencian claramente este hecho. 
El primero de los capítulos («Lope de Vega y los portugueses: depreciación y glorificación del rey don Juan Il», pp. 17-37) comenta la atención que presta Lope a los temas portugueses y en especial al personaje de Juan II. Lejos de ser un rasgo específico de Lope (también se ha hablado mucho del «lusitanismo» de Tirso, por ejemplo) señala AAL que esa «conciencia hispánica», como había apuntado ya en la introducción, es general y se advierte en otros muchos (ver p. 20). Sea como fuere, es evidente en Lope esta presencia de lo portugués, en dos variantes de tratamiento, que se relacionan con los géneros o las convenciones serias/cómicas: por un lado la imagen del portugués valeroso, noble, en la línea de la «aceptación de los portugueses como parte indivisible de la identidad española» (p. 21); por otra la serie de tópicos jocosos que describen al portugués fanfarrón y seboso (derretido de amor), como expresan muchos chistes y caricaturas. No son realmente visiones contradictorias, ya que responden a tratamientos diferentes según el tono del género de texto. AAL aporta interesantes ejemplos de diversas perspectivas en distintas obras de Lope, y examina con más precisión la figura de Juan II, personaje central en la trama de tres piezas lopianas (la dilogía de El príncipe perfecto y El duque de Viseo). Mientras que en las primeras Juan II es un hombre virtuoso y justo, en la última toma el aspecto de soberano despótico. AAL revisa con sindéresis los principales motivos de estos tratamientos, las fuentes históricas, la visión del poder y su legitimación o deslegitimación, y la inserción de las obras de Lope y sus posibles intenciones en sus contextos históricos y políticos, en relación con la etapa de la monarquía dual. No se escapan a la agudeza crítica de AAL los análisis que han marcado la interpretación de las comedias estudiadas, que comenta demorada y autorizadamente. Destaca en todo caso la observación de los problemas anejos al ejercicio del poder y la misma función de las comedias sobre el rey portugués, que en última instancia podrían entenderse como «dos formas distintas de servir, además de a la Casa de Braganza, a los intereses absolutistas de Felipe IIl» (p. 37), aunque persiste el problema de explicar la defensa de la Casa de Braganza en ese contexto.

No menos finura muestra en el segundo capítulo, la reflexión sobre El alcalde de Zalamea en el contexto peninsular. AAL ofrece en las primeras páginas de este capítulo una comparación iluminadora de las versiones de Lope (atribuida) y la canónica de Calderón, para proseguir con el comentario del personaje protagonista y sobre todo con el análisis desde perspectivas 'lusitanas' del violador Ataide, de apellido de origen portugués, aspecto, como apunta AAL no demasiado perceptible, pero tampoco invisible (p. 51). Considera AAL que no es casual que este personaje evoque de algún modo prejuicios contra los portugueses en el ámbito de las tensiones políticas hispano-lusas (cabe recordar que la acción de El alcalde de Zalamea se sitúa precisamente en el momento en que Felipe II asciende al trono portugués).

A «Las quinas de Portugal, de Tirso de Molina y la censura salazarista» se dedica el capítulo 3, en el que se revisa la prohibición en marzo de 1968 de la comedia de Tirso por la censura del régimen de Oliveira Salazar. El episodio es sumamente curioso y significativo, y constituye más que una mera anécdota pintoresca, sobre todo si se tiene en cuenta que en 1947 dicha censura había aprobado La casa de Bernarda Alba de Lorca, sin cortes. Los dos informes de la censura relativos a la comedia tirsiana revelan, como señala AAL una «falta de sentido estético y de 
conocimiento de historia literaria» (p. 56), pero revelan, sobre todo, a mi juicio, el temor de comprometerse con un dictamen que pudiera ser revocado por 'la autoridad superior', ante la misma desorientación que la obra provoca en los censores. Trata de un mito fundacional portugués, sí, pero el primer censor capta cierta falta de decoro en el tratamiento de figuras fundamentales de la historia patria. Para el estudioso los censores «no creían que un escritor español pudiera alabar con seriedad y sin ironía el principal mito fundador de la nación portuguesa» (p. 77). El análisis que hace AAL de los mecanismos censores y el comentario de algunos casos significativos es ciertamente interesante y documentado y ofrece, al hilo de su tema central, una excelente glosa de la pieza de Tirso y de la importancia para la historia y cultura portuguesa del suceso histórico de la batalla de Ourique y de su transformación en mito nacional.

El capítulo 4 se ocupa, finalmente de «La construcción de lo grotesco en $O$ fidalgo aprendiz de Francisco Manuel de Melo», importante personaje y escritor bilingüe. Solo cabría apuntar, quizá, que la referencia teórica de Kayser no es muy útil para el grotesco del Siglo de Oro, ya que Kayser se inclina hacia una visión más 'romántica', de lo grotesco onírico, terrorífico, numinoso, mientras que el arte grotesco aurisecular se inclina a las formulaciones más o menos 'bajtinianas', y queda representado por los efectos ambiguos o mixtos en el receptor, que mezclan la risa con la repulsión y privilegian la caricatura y las formas de turpitudo et deformitas. La información y exégesis de los personajes grotescos que Melo ofrece en su obra teatral revela que los elementos constitutivos de la obra responden a la habitual fauna del retablo grotesco aurisecular, y que en efecto, no es aceptable una lectura biografista, que AAL niega con muy buenas razones (p. 87).

Dejando aparte, como he avanzado ya, la sección de la Edad de Plata, en lo que se refiere al Siglo de Oro, AAL ofrece una serie de páginas muy bien informadas, excelentemente articuladas y sin duda de relevancia en este camino -necesario de transitar, merecedor de agradecimiento- de ilustrar las relaciones hispanoportuguesas, que eran en el Siglo de Oro unas relaciones de familia, mucho más estrechas de lo que a veces parece sugerir el olvido posterior de buena parte de la crítica histórica y literaria, en cuyo remedio trabajos tan meritorios, tan bien documentados y escritos con gran claridad y conocimiento de los temas, como este de António Apolinário Lourenço, constituyen un importante avance. 